\title{
ANALISIS PERBANDINGAN PENERAPAN PEMBELAJARAN TATA BAHASA CHINA ANTARA PEMBELAJARAN TATAP MUKA DENGAN KOMBINASI PEMBELAJARAN JARAK JAUH DAN TATAP MUKA
}

\author{
Yi Ying \\ Chinese Department, BINUS UNIVERSITY \\ Kampus Kijang, Jl. Kemanggisan Ilir III No. 45, Kemanggisan/Palmerah \\ Jakarta Barat 11480, yi_ying@binus.ac.id
}

\begin{abstract}
In Faculty of Literature, all these time the grammar teaching was only done face to face. A long with the application of Multi Channel Learning in UBiNus, a grammar learning using combination method of long distance and face to face was developed. To know which one the most suitable and effective learning method, also to evaluate all the running method used, the Chinese Department will conduct comparative research among conventional class, combination between offclass and MCL, MCL without off-class. The method used are quantitative and qualitative research method. Based on the research, it can be concluded that the student grade of MCL class is higher than the student grade of MCL Off Class and the Face to Face class.
\end{abstract}

Keywords: e-Learning, grammar, China language, multi channel learning

\begin{abstract}
ABSTRAK
Di Fakultas Sastra, selama ini pengajaran tata bahasa hanya melalui tatap muka langsung. Seiring dengan penerapan sistem pembelajaran Multi Channel Learning di UBiNus maka dikembangkanlah metode pembelajaran tata bahasa model kombinasi pembelajaran jarak jauh dan tatap muka. Untuk mengetahui metode pembelajaran yang paling tepat dan efektif, sekaligus mengevaluasi semua metode yang sudah dijalankan selama ini, Jurusan Sastra China akan melaksanakan penelitian perbandingan antara kelas konvensional, gabungan off-class dan MCL, dan MCL tanpa off-class. Metode yang akan digunakan adalah metode kuantitatif dan kualitatif. Berdasarkan penelitian disimpulkan bahwa nilai mahasiswa kelas MCL lebih unggul dibandingkan nilai mahasiswa kelas MCL Off Class dan kelas Face to Face (Konvensional).
\end{abstract}

Kata kunci: e-Learning, tata bahasa, bahasa China, multi channel learning 


\section{PENDAHULUAN}

\section{Pemanfaatan Teknologi dan Pendidikan Bahasa}

Seiring dengan perkembangan teknologi, semakin banyak bidang yang memanfaatkan kemajuan di bidang maya. Komunikasi antarmanusia dapat diselesaikan tanpa harus bertemu muka. Hal itu dapat membantu penghematan biaya bagi banyak perusahaan. Bahkan, orang pun dimudahkan dalam berbelanja. Tanpa harus membuat paspor dan membayar fiskal yang mahal, orang dapat berbelanja lintas negara. Bahkan, dalam mencari pasangan hidup pun, tidak sedikit orang yang memanfaatkan jasa teknologi maya ini. Pemanfaatan teknologi ini tidak hanya di bidang ekonomi saja tetapi bidang pendidikan pun sudah mulai melirik dunia maya. Dimulai dari pendaftaran ulang, melihat nilai, sampai kuliah jarak jauh. Kuliah jarak jauh atau off-class dengan menyediakan semua materi ajar di web-site membuat mahasiswa tidak perlu pergi ke kampus sehingga dapat menghemat waktu dan biaya transportasi.

Di Fakultas Sastra, selama ini pengajaran tata bahasa hanya melalui tatap muka langsung. Seiring dengan penerapan sistem pembelajaran Multi Channel Learning di UBiNus maka dikembangkanlah metode pembelajaran tata bahasa model kombinasi pembelajaran jarak jauh dan tatap muka. Namun, sistem MCL ini masih menjadi perdebatan dalam pengajaran bahasa. Banyak hal yang mengundang pro dan kontra, baik hal yang secara langsung berhubungan dengan kegiatan pembelajaran, seperti komunikasi dosen dan mahasiswa, tingkat pemahaman mahasiswa terhadap suatu materi tanpa mendapatkan penjelasan dari dosen, maupun hal yang bersifat tidak langsung, seperti ketersediaan sambungan internet di tempat tinggal mahasiswa, biaya untuk sambungan internet, dan lain-lain. Oleh karena itu, untuk mengetahui metode pembelajaran yang paling tepat dan efektif, sekaligus mengevaluasi semua metode yang sudah dijalankan selama ini, Jurusan Sastra China akan melaksanakan penelitian perbandingan antara kelas konvensional, gabungan off-class dan MCL, dan MCL tanpa off-class.

\section{Tata Bahasa sebagai Momok Pembelajaran}

Bagi sebagian besar orang, tata bahasa merupakan aturan yang susah diingat, karena tidak seperti rumus matematika, dalam tata bahasa ada banyak rumus dengan tidak sedikit pengecualian pada masing-masing aturan tata bahasa. Hal itu membuat sebagian orang mengangkat tangan dan memilih melupakan pengecualian tersebut dengan alasan pada kenyataannya tanpa tata bahasa yang benar pun komunikasi masih dapat berjalan. Tidaklah heran jika bahasa yang didengar dan dibaca setiap hari tidak sesuai dengan bentuk standar dari tata bahasa yang baku.

Namun, masalah di atas bukan semata-mata kesalahan pembelajar. Metode yang pengajaran yang melulu menonjolkan struktur bahasa akan membuat pembelajar kehilangan motivasi. Oleh karena itu, pendekatan komunikatif dalam pengajaran bahasa lebih banyak dipakai, khususnya di negara yang memperhatikan pentingnya pendidikan. Tatabahasa tidak dihadirkan sebagai pemain utama dalam penguasaan bahasa, melainkan hanya sebagai pemain pembantu. Ungkapan bahasa dalam bentuk percakapan dan fungsinya lebih diutamakan sehingga lebih memberikan motivasi kepada pembelajaran karena target pembelajaran adalah MAMPU BERKOMUNIKASI, bukan MENGUASAI TATABAHASA, sekalipun judul mata kuliah adalah TATABAHASA.

\section{Latar Belakang Pembelajar dengan Bahasa Ibu Bahasa China}

Di Indonesia, ada beberapa daerah yang penduduk suku China-nya dapat berbahasa China dari kecil. Akan tetapi, bahasa yang mereka kuasai adalah bahasa perolehan, bukan hasil pembelajaran. Di samping itu, bahasa China mereka telah mendapat pengaruh dari bahasa daerah domisili mereka, baik 
dari segi tata bahasa maupun fonologi, misalnya saja bahasa China di Jawa Tengah yang kental dengan logat Jawa dan dipengaruhi oleh tata bahasa setempat sehingga ketika mereka berbahasa China, lebih terdengar seperti berbahasa Jawa. Sebagian besar mahasiswa Jurusan Sastra China di UBinus berasal dari suku China dengan latar belakang tersebut. Bahasa ibu mereka yang bukan bahasa China Standar atau Putonghua terkadang merupakan kendala dalam penguasaan tatabahasa yang baik dan benar.

Hal tersebut akan membawa dampak yang kurang baik ketika mereka akan mencari kerja atau bekerja sebagai tenaga kerja profesional (sekretaris) di perusahaan yang membutuhkan kemampuan bahasa yang mencakup empat aspek (mendengar, berbicara, membaca, menulis) secara menyeluruh.

\section{Peranan Bahasa China dalam Perekonomian Dunia dan Globalisasi}

Sebelum ekonomi China menguat seperti sekarang ini, telah diketahui bersama bahwa PBB telah menetapkan bahasa China sebagai bahasa internasional kedua setelah bahasa Inggris. Sekarang ini, secara ekonomi negara China menguat, dibuktikan dari cadangan devisanya yang terbanyak di seluruh dunia, menyingkirkan Jepang yang selama ini berada pada urutan pertama. Seiring dengan globalisasi ekonomi dunia, barang-barang produksi China mulai merambah pasaran dunia bersaing dengan produksi negara maju, seperti Jepang. Oleh karena itu, perusahaan yang mengadakan hubungan dagang dengan China atau mengimpor barang dari China juga berlomba-lomba mencari tenaga kerja yang dapat berbahasa China dengan benar dan tepat.

Tidak dapat juga menutup mata bahwa dengan globalisasi, semakin banyak tenaga asing yang masuk ke Indonesia untuk mencari kerja. Jika penguasaan bahasa China mereka lebih baik dibandingkan dengan lulusan dalam negeri maka tidak heran jika lulusan dalam negeri tidak terserap oleh pasar yang membutuhkan tenaga kerja yang mampu berkomunikasi dengan baik.

\section{e-Learning}

Apa itu e-Learning? Menurut Ruth Colvin Clark dan Richard E. Mayer (2003:13), e-Learning adalah suatu instruksi yang menggunakan komputer, baik melalui CD Rom, internet maupun intranet dengan ketentuan fitur berikut: Memuat bahan yang relevan dengan tujuan pembelajaran; Menggunakan metode pengajaran, seperti pemberian contoh dan pelatihan untuk membantu pembelajaran; Menggunakan elemen media, seperti tulisan, gambar untuk menyalurkan isi dan metode; Membangun pengetahuan dan kemampuan yang mendukung tercapainya tujuan pembelajaran secara individual, dan juga meningkatkan performa organisasi.

Dasar e-Learning terbagi dalam dua jenis. Pertama, yaitu Synchronous Training adalah tipe pelatihan di mana proses pembelajaran terjadi pada saat yang sama ketika pengajar sedang mengajar dan murid sedang belajar. Jenis ini lebih banyak digunakan dalam seminar atau konferensi yang pesertanya berasal dari beberapa negara. Jadi, training ini sifatnya mirip pelatihan di ruang kelas. Namun, kelasnya bersifat maya (virtual) dan peserta tersebar di seluruh dunia dan terhubung melalui internet.

Kedua, Asynchronous Training adalah tipe pelatihan tidak pada waktu yang bersamaan. Jadi, seseorang dapat mengambil pelatihan pada waktu yang berbeda dengan pengajar memberikan pelatihan. Pelatihan disalurkan berupa paket pelajaran yang dapat dijalankan di komputer manapun dan tidak melibatkan interaksi dengan pengajar atau pelajar lain. Paket pelajaran berbentuk bacaan dengan animasi, simulasi, permainan edukatif, maupun latihan atau tes dengan jawabannya. Akan tetapi, ada pelatihan Asynchronous Training yang terpimpin, yaitu pengajar memberikan materi pelajaran lewat internet dan peserta pelatihan mengakses materi pada waktu yang berlainan. Pengajar 
dapat pula memberikan tugas atau latiihan dan peserta mengumpulkan tugas lewat e-mail. Peserta dapat berdiskusi atau berkomentar dan bertanya melalui bulletin board.

\section{Mengapa Harus e-Learning?}

Perubahan praktik pendidikan pun harus dilakukan di dunia akademis. Beberapa tahun yang lalu, siswa hanya disibukkan kegiatan belajar kurang lebih 5 jam sehari. Akan tetapi, sekarang siswa masih mengikuti kelas bimbingan belajar, praktik ekstrakurikuler, dan kelas bahasa asing di luar sekolah. Harus ditanyakan juga alasan orang tua mengirimkan anaknya ke sekolah jika nanti membawa anaknya ke kelas bimbingan belajar untuk mempelajari topi yang sama pula. Hal tersebut menandakan praktik pengajaran di sekolah yang belum efektif sepenuhnya (Zhuang dan Effendi, 2005:3).

Mereka membutuhkan teknologi yang dapat menyediakan pendidikan dan pelatihan yang pengadaannya cepat, metodenya lebih efektif, dan persiapannya lebih singkat. Menurut survei yang diadakan ASTD (American Society for Training and Development) tahun 2004 mengungkapkan bahwa hampir $60 \%$ perusahaan di Amerika telah atau mulai mengimplementasikan e-Learningdi perusahaan mereka. e-Learning pun telah melanda dunia akademis. Di Amerika Serikat, e-Learning telah digunakan di hampir 90\% universitas yang memiliki lebih dari 10.000 siswa.

\section{Keuntungan e-Learning}

Adapun keuntungan dalam implementasi e-Learning adalah sebagai berikut. Pertama, biaya. Biaya pelatihan otomatis berkurang. Dengan adanya $e$-Learning, perusahaan tidak perlu mengeluarkan uang untuk menyewa pelatih dan ruang kelas serta transportasi peserta dan pelatih. Selain itu, perusahaan dapat menghemat biaya akomodasi bagi pelatih atau pelajar. Kedua, fleksibilitas waktu. Tim pelaksana pelatihan sering merasa kesulitan menyesuaikan waktu beberapa karyawan yang dilatih. Hal itu karena untuk mengikuti pelatihan di kelas, karyawan harus meninggalkan pekerjaannya selama satu atau dua hari. Denagn tuntutan kompetisi perusahaan yang kian meningkat, kekurangan karyawan selama itu akan mengganggu produktivitas perusahaan. Oleh karena itu, tidak heran karyawan dan atasannya kurang menyenangi pelatihan yang memakan waktu lama. Dengan e-Learning, memungkinkan karyawan menyesuaikan waktu belajar dengan waktu kerja. Karyawan dan pelajar mudah mengakses e-Learning dan juga dapat dengan mudah meninggalkan pelajaran tersebut dan melakukan pekerjaan lainnya yang lebih penting. Banyak program pelajaran e-Learning yang memiliki fasilitas bookmark yang memungkinkan mereka saat kembali belajar dapat memulai dari bagian yang terakhir kali dia tinggalkan sehingga mereka tidak perlu mengulang pelajaran sebelumnya.

Ketiga, fleksibilitas tempat. Biasanya para karyawan atau pembelajar enggan bepergian jauh hanya untuk mengikuti pelatihan, adanya $e$-Learning membuat karyawan santai mengakses pelatihan e-Learning di kantor, bahkan di meja kerja. Selama komputer terhubung dengan server e-Learning maka mereka dengan mudah mengaksesnya. Keempat, fleksibilitas kecepatan pembelajaran. Kemampuan belajar tiap orang berbeda-beda. Oleh karena itu, wajar bila di dalam suatu kelas ada siswa yang mengerti secara cepat dan ada yang harus mengulang pelajaran untuk memahaminya. Akan tetapi, karena pelatih atau guru di kelas mengajar dengan kecepatan sama untuk semua siswa maka siswa yang lebih lambat akan sulit memahaminya. Terlebih lagi guru sering tidak memiliki waktu untuk menjawab pertanyaan siswa atau berdiskusi setelah waktu pelajaran di kelas habis. Siswa menjadi frustasi. Siswa yang lebih cepat menginginkan lebih bayak materi sedangkan siswa yang lebih lambat menginginkan pengulangan pelajaran. $e$-Learning dapat disesuaikan dengan kecepatan belajar masing-masing siswa. Siswa mampu mengatur sendiri kecepatan pelajaran yang diikuti. Apabila dia masih tidak mengerti, dia dapat mengulang pelajaran tersebut sampai dia mengerti betul materi tersebut. 
Kelima, standarisasi pengajaran. Anda pasti pernah memiliki guru atau pelatih favorit yang dapat mengajar dengan baik sehingga sehingga materi sesulit apapun mudah diserap. Sebaliknya, penjelasan guru bukan favorit terasa sulit dimengerti. Hal tersebut disebabkan perbedaan kemampuan dan metode pengajaran yang diterapkan guru. Perbedaan tersebut menyebabkan kualitas pengajaran sulit dijaga karena guru favorit tidak mungkin diminta mengajarkan semua pengajaran. Terlebih lagi, guru favorit pun dapat merasa tidak fit saat mengajar sehingga kualitas pengajaran menurun. ELearningdapat menghapuskan perbedaan tersebut. Pelajaran e-Learning selalu memiliki kualitas sama setiap kali diakses dan tidak tergantung dari suasana hati pengajar.

Keenam, efektivitas pengajaran. e-Learning yang didesain dengan intruksional desain yang baik membuat karyawan atau pelajar lebih mengerti isi pelajaran. Penyampaian pelajaran e-Learning dapat berupa simulasi dan kasus menggunakan bentuk permainan dan menerapkan teknologi animasi canggih. Bentuk pembelajaran tersebut dapat membantu proses pembelajaran mempertahankan minat belajar. Ketujuh, kecepatan distribusi. Kemajuan tehnologi yang pesat menuntut suatu pelatihan tehnologi baru dilaksanakan secepatnya dan menjangkau area luas secara singkat. Melihat geografis Indonesia bukan hal aneh bila suatu perusahaan dapat menerapkan teknologi canggih di kantor pusat di Jakarta sedangkan kantor cabang yang terpencil tidak mengetahui teknologi tersebut. Kebijakan baru perusahaan yang ditetapkan kantor pusat kadang memerlukan pelatihan agar karyawan dapat memahaminya. e-Learning dapat cepat menjangkau karyawan yang berada di luar wilayah pusat. Tim perancang pelatihan hanya perlu mempersiapkan bahan pelatihan secepatnya dan menginstal hasilnya di server pusat e-Learning sehingga semua komputer yang terhubung ke server dapat langsung mengakses.

\section{PEMBAHASAN}

\section{Metode yang Digunakan}

Metode yang akan digunakan adalah metode kuantitatif dan kualitatif. Metode kuantitatif mencakup data dari survei nilai tatabahasa dan angket sedangkan yang dimaksud dengan metode kualitatif adalah pertanyaan yang bersifat wawancara melalui angket. Berikut rincian masing-masing metode. Data kuantitatif yang akan digunakan sebagai bahan perbandingan adalah nilai UTS dan UAS dari mahasiswa tingkat satu (tahun pertama) selama dua semester dari tiga kelas pelajaran tatabahasa, yaitu 1. kelas konvensionl atau sistem face to face murni, 2. MCL + off class, 3. MCL tanpa off-class. Pada kelas MCL OFC, aktivitas yang dilakukan mahasiswa pada waktu OFC terdiri dari tiga bagian. Bagian pertama adalah memberikan bahan bacaan dari website kepada para mahasiswa melalui discussion board. Bacaan yang ada sudah ada cara bacanya oleh penutur asli. Setelah membaca teks, mahasiswa menjawab pertanyaan. Tujuan aktivitas ini adalah untuk meningkatkan kemampuan membaca dengan nada dan lafal yang benar serta menambah kosa kata.

Bagian kedua adalah dengan memberikan alamat website yang berisi percakapan sederhana dan menugaskan mahasiswa meringkas percakapan tersebut dengan kata-kata sendiri. Jawaban mahasiswa di-posting melalui forum discussion board. Pada pertemuan berikutnya, mahasiswa menceritakan isi percakapan tersebut dengan kata-kata sendiri. Keuntungan aktivitas ini adalah mahasiswa mampu mendengar percakapan dengan nada dan lafal yang tepat dari penutur asli. Hal itu diharapkan dapat meningkatkan kemampuan mendengar mahasiswa. Bagian ketiga adalah mahasiswa meringkas tata bahasa dari web-site yang diberikan dan kemudian mengerjakan latihan tata bahasa yang disediakan berupa menyusun kalimat yang diacak dan menyusun kalimat dari kosa kata yang diberikan. 
Pada kelas MCL non OFC, mahasiswa tetap mengerjakan bahan latihan seperti kelas MCL OFC, bedanya mereka mengerjakannya tidak pada waktu OFC. Dengan demikian, dapat dikatakan beban tugas mandiri mahasiswa kelas ini lebih berat dibandingkan dua kelas lainnya.

Angket yang akan dibuat sesuai dengan kondisi masing-masing kelas, dengan substansi yang sama tetapi pertanyaan berbeda. Angket ditujukan untuk menanyakan hal berikut: Kelebihan dan kekurangan dari ketiga sistem, menyangkut biaya (perbandingan biaya transportasi ke kampus dan biaya untuk mendownload bahan atau online), waktu (transportasi ke kampus, pergi ke warnet), kemudahan menangkap/mengerti materi, peningkatan kemampuan berbahasa yang mencakup empat aspek komunikasi (mendengar, berbicara, membaca, menulis) yang dirasakan, kemudahan komunikasi antara dosen dan mahasiswa, dan lain-lain; Kendala pembelajaran dari ketiga sistem, seperti ketersediaan sambungan internet di rumah, jenis server yang digunakan, keberadaan warnet di sekitar rumah/kos, kelengkapan perangkat lunak di warnet, kepemilikan komputer yang dilengkapi dengan perangkat lunak bahasa mandarin,kemacetan lalu-lintas, banjir, kesibukan dosen, dan lain-lain.

Pertanyaan yang ditujukan akan bersifat tertutup (disediakan pilihan) dan terbuka (jawaban bebas dari responden). Selain itu, akan diteliti juga variabel yang mempengaruhi pembelajaran, seperti: Bahasa ibu (bahasa daerah Indonesia atau rumpun bahasa China, seperti Hokkian, Hakka, Tio Ciu, dan lain-lain); Bahasa yang dipergunakan sehari-hari; Kemampuan berbahasa China sebelum belajar secara formal di Ubinus, mencakup tempat memperoleh kemampuan (percakapan di rumah, kursus) dan tingkat kemampuan (dapat berkomunikasi sederhana tetapi tidak dapat membaca dan menulis, mampu membaca dan menulis).

\section{Hasil Perbandingan Nilai UTS dan UAS}

Dasar pengukuran terhadap keberhasilan pengajaran Bahasa China adalah dari nilai UTS dan UAS mahasiswa yang mendapatkan nilai A, B, dan C dari masing-masing kelas. Adapun kelas yang dimaksud terbagi menjadi tiga kelas, yaitu Kelas MCL OFC dan Kelas MCL Non OFC, mahasiswa selain mendapatkan bahan ajar dari buku paket, juga mendapatkan materi pendukung dari website. Dengan demikian, mahasiswa mendapatkan tambahan kosa kata, contoh kalimat, percakapan, dan mendengar di luar buku paket; Kelas Konvensional, mahasiswa hanya mendapatkan bahan ajar dari buku paket tanpa tambahan materi pendukung dari website.

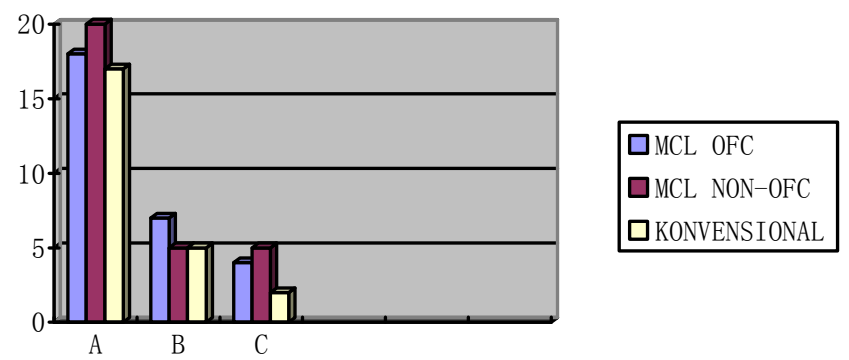

Gambar 1 Hasil Perbandingan Nilai UTS dan UAS

Berdasarkan hasil tersebut, dapat dilihat bahwa mahasiswa yang mendapakan nilai A dari kelas MCL non OFC lebih besar dibandingkan mahasiswa kelas MCL OFC dan mahasiswa kelas konvensional. Hal itu menunjukan bahwa pengajaran Bahasa China dari kelas MCL lebih unggul dibandingkan dua kelas lainnya. Dengan demikian, dapat disimpulkan mata kuliah Bahasa China I lebih efektif jika dilakukan dengan tatap muka dengan tambahan materi di luar text book. 


\section{Hasil Kuesioner}

Kuesioner yang terdiri dari 20 pertanyaaan dibagikan kepada 90 mahasiswa dan hanya 71 mahasiswa yang mengembalikan. Tujuan pembagian kuesioner adalah untuk mendapatkan data yang akurat tentang kondisi pembelajaran Bahasa China I dan masukan untuk perbaikan proses pengajaran untuk tahap selanjutnya. Berikut ini adalah hasil penyebaran kuesioner beserta penjelasannya.

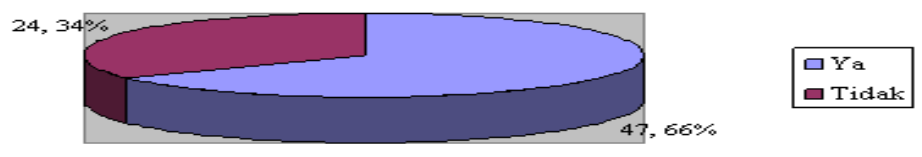

Gambar 2 Dasar Bahasa China

Dari Gambar 2 diketahui bahwa sebagian besar mahasiswa mempunyai dasar bahasa China. Dengan demikian, tidak mengherankan jika sebagian besar nilai UTS dan UAS mahasiswa seperti yang terlihat pada Gambar 1 adalah A. Pelajaran Bahasa China I masih sangat mendasar, dengan demikian mahasiswa yang sudah mempunyai dasar tidak mengalami banyak kesulitan dalam menguasai bahan ajar.

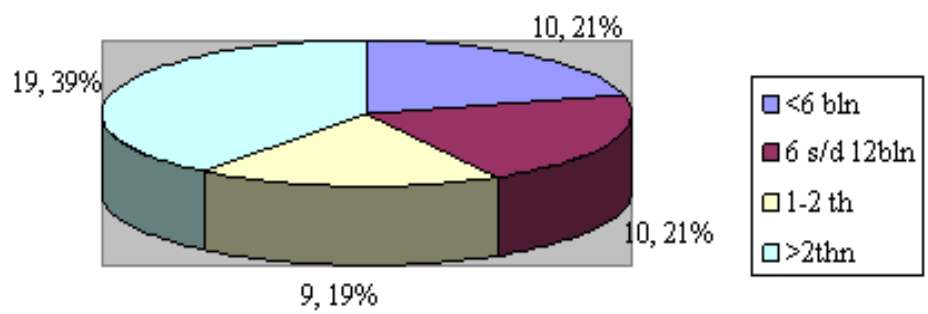

Gambar 3 Lama Belajar

Dari Gambar 3 dapat diketahui bahwa dari 71 mahasiswa yang belajar bahasa China, ada 19,39\% mahasiswa yang mempunyai dasar bahasa China lebih dari 2 tahun sedangkan mahasiswa yang jangka waktu belajarnya kurang dari 6 bln dan antara 6-12 bulan sebanyak 10.21\%. Data itu menunjukkan bahwa sebagian besar mahasiswa sudah mempunyai dasar bahasa China sebelum kuliah di jurusan sastra China UBiNus.

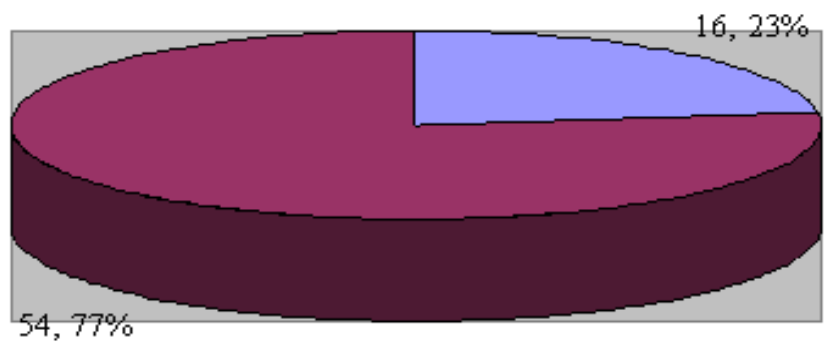

Gambar 4 Lingkungan Berbahasa 
Gambar 4 menunjukkan sebagian besar mahasiswa tidak berkomunikasi dalam bahasa China dengan orang tuanya. Dengan demikian, dapat disimpulkan bahwa meskipun mahasiswa mempunyai kemampuan dasar bahasa China, belum tentu kemampuan tersebut mereka dapat di lingkungan keluarga karena sebagian besar orang tua mereka tidak dapat berbahasa China. Kemungkinan besar adalah lewat sekolah dan tempat kursus.

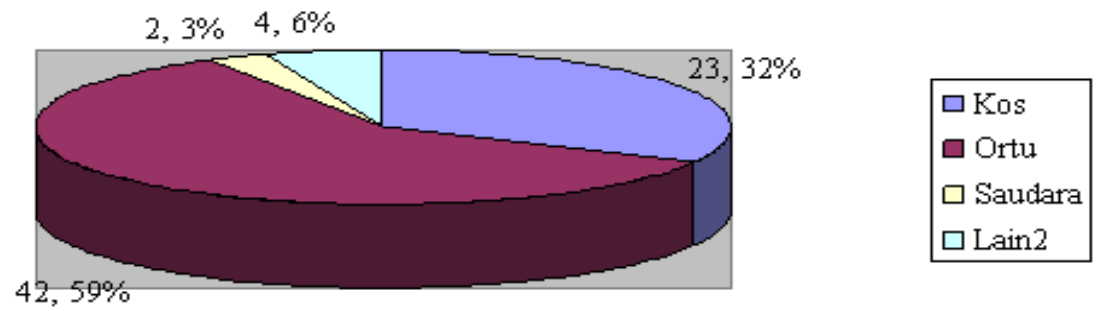

Gambar 5 Tempat Tinggal

Dari Gambar 5 dapat diketahui bahwa sebagian besar mahasiswa tinggal dengan orang tuanya (bukan mahasiswa luar daerah). Kemungkinan besar para orang tua tersebut tidak dapat berbahasa China sehingga dapat disimpulkan pengaruh orang tua juga sangat besar dalam mendukung hasil belajar putra-putrinya.
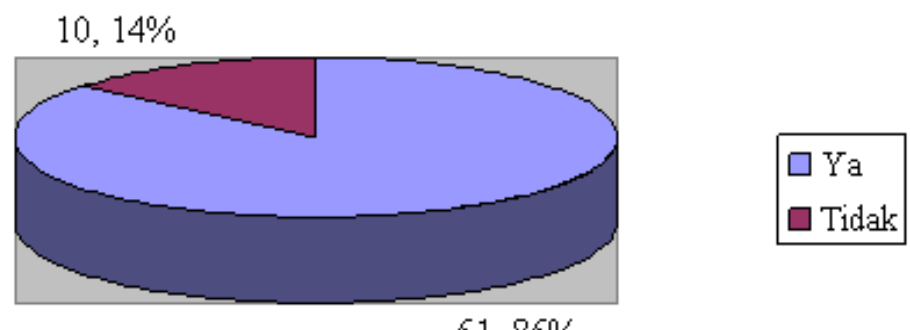

$61,86 \%$

Gambar 6 Memiliki Komputer

Gambar 6 menunjukkan sebagian besar mahasiswa memiliki komputer pribadi. Dengan demikian, jika pengajaran dengan MCL tidak akan menyulitkan karena mahasiswa sdah mempunyai sarana untuk belajar dengan sistem MCL.
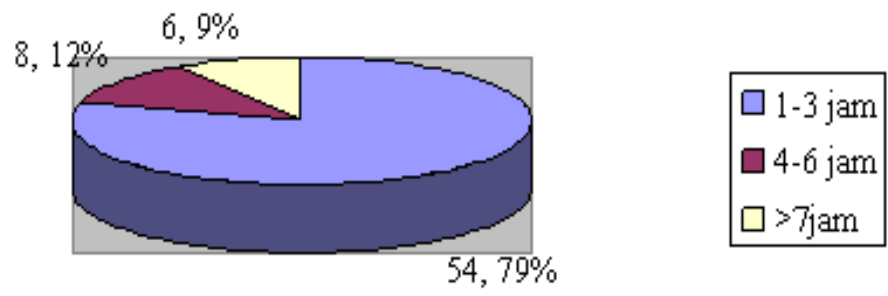

Gambar 7 Lama Akses Internet 
Dari data tersebut terlihat bahwa sebagian besar mahasiswa hanya mengakses internet selama 1-3 jam seminggu. Dengan demikian, dapat dirata-rata dalam sehari waktu untuk mengakses internet tidak sampai 10 menit. Hal itu sangat disayangkan mengingat sebagian besar mahasiswa mempunyai komputer di rumah. Jika mahasiswa lebih diaktifkan untuk mengerjakan tugas on-line atau mencari bahan di internet yang mendukung pembelajaran, kemungkinan waktu mengakses internet selama seminggu dapat meningkat.

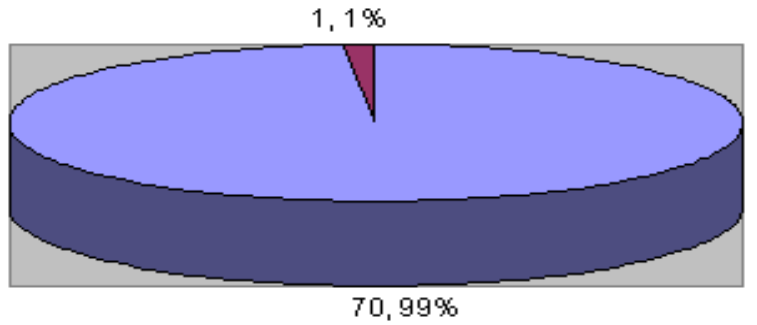

$$
\begin{aligned}
& \text { 口Ya } \\
& \text { aTidak }
\end{aligned}
$$

Gambar 8 Keefektivan Bahasa China I

Dari gambar tersebut dapat dilihat bahwa sebagian besar mahasiswa merasa pelajaran Bahasa China I efektif, dalam arti dapat berguna bagi mereka dalam menguasai bahasa Mandarin. Jika mahasiswa sudah merasa puas terhadap pembelajaran mata kuliah Bahasa China I maka dengan otomatis nilai mereka juga akan berpengaruh.

\section{$12,14 \%$}

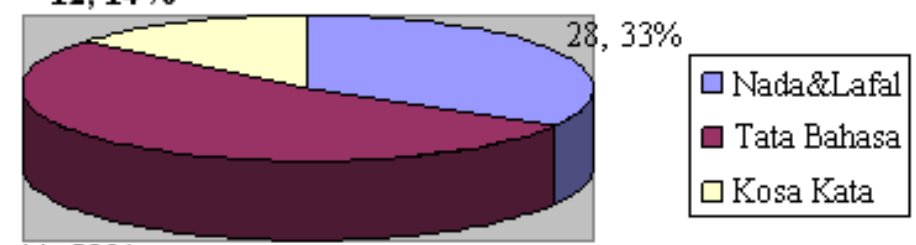

$44,53 \%$

Gambar 9 Kesulitan dalam Belajar Bahasa China I

Sebagian besar mahasiswa merasa dalam mempelajari Bahasa China I yang paling sulit adalah tata bahasa. Dalam hal ini yang dimaksud tata bahasa adalah menyusun kalimat dengan konteks tata bahasa China. Hal itu dapat dimengerti karena tata bahasa China bertolak belakang dengan tata bahasa Indonesia. Selama ini mahasiswa Indonesia sudah biasa menyusun kalimat dalam bahasa Indonesia.

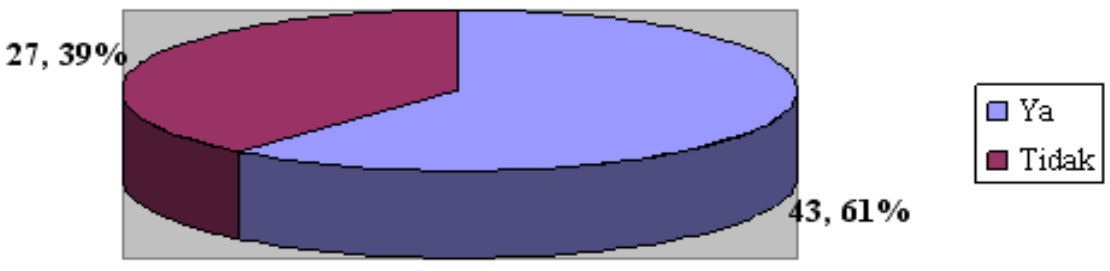

Gambar 10 MCL Bahasa China I

Sebagian besar mahasiswa setuju jika pengajaran Bahasa China I dengan cara MCL. Dengan demikian, mahasiswa mendukung penuh pembelajaran MCL. Hal itu sangat menggembirakan karena mahasiswa menyadari perlunya kemajuan teknologi dalam mendukung proses belajar mengajar dan membantu mereka untuk lebih menguasai bahan ajar yang ada. 


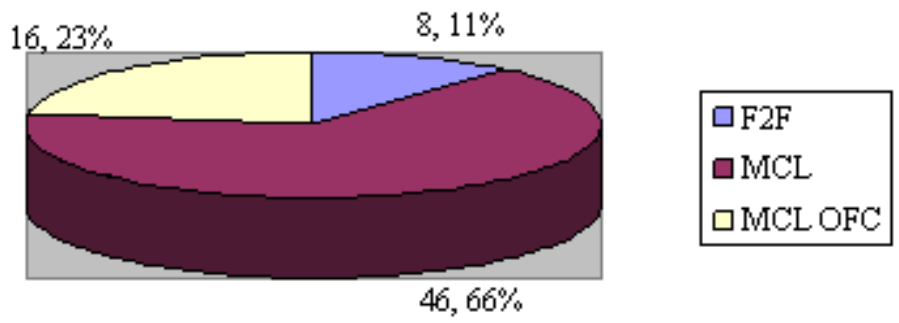

Gambar 11 Sistem Pembelajaran

Sebagian besar mahasiswa mendukung pembelajaran dengan MCL. Sistem pembelajaran F2F adalah pembelajaran tatap muka tanpa bahan pendukung lain, seperti animasi percakapan, kosa kata, nada, dan lafal. Sistem pembelajaran MCL adalah tatap muka dengan bahan pendukung lain, seperti animasi percakapan, kosa kata, nada, dan lafal. Sistem pelajaran MCL OFC adalah kombinasi tatap muka dan OFC dengan bahan pendukung lain, seperti animasi percakapan, kosa kata, nada, dan lafal.

\section{$7,10 \%$}
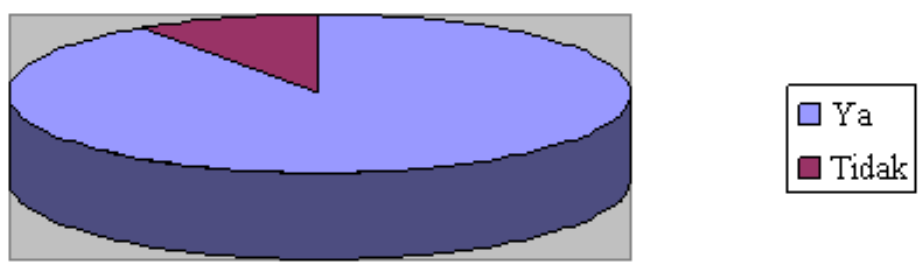

$64,90 \%$

Gambar 12 Perangkat Ajar Nada dan Lafal

Sebagian besar mahasiswa setuju adanya perangkat ajar di luar jam kuliah yang dapat dipakai untuk mendukung pembelajaran nada dan lafal Bahasa China I. Dengan demikian, mahasiswa menyadari bahwa waktu untuk belajar di kelas tidak cukup, mereka harus belajar di luar kelas supaya dapat membunyikan dan melafalkan dengan tepat. Akan tetapi, mereka jika jawaban sudah tersedia, akan memudahkan mereka untuk belajar.

\section{$8,11 \%$}

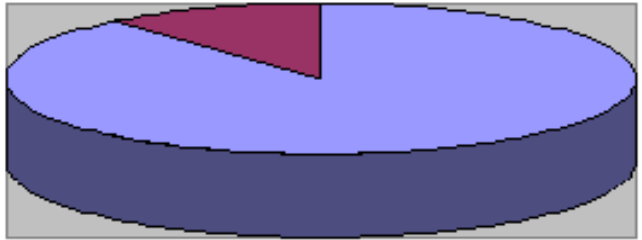

$62,89 \%$

\section{$\square \mathrm{Ya}$ \\ $\square$ Tidak}

Gambar 13 Perangkat Ajar Kosa Kata

Sebagian besar mahasiswa setuju adanya perangkat ajar di luar jam kuliah yang dapat dipakai untuk mendukung pembelajaran kosakata. Selain itu, mahasiswa merasa terbantu dalam menghapalkan kosa kata jika ada latihan dan jawabannya. 

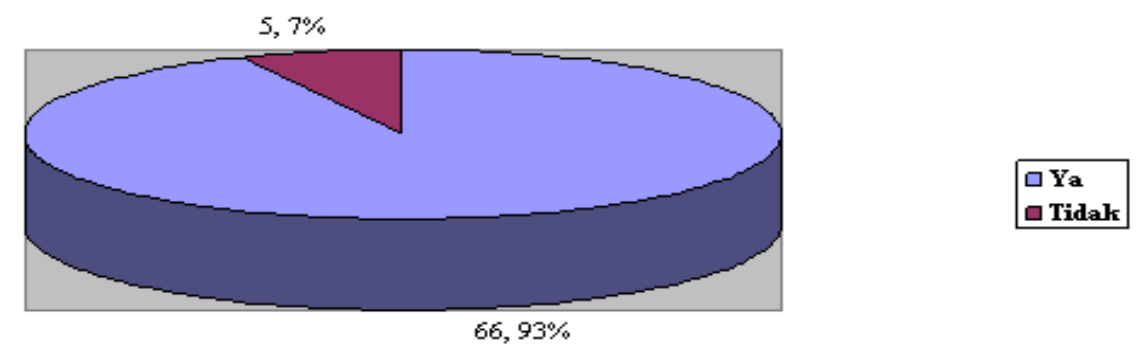

Gambar 14 Perangkat Ajar Tata Bahasa

Sebagian besar mahasiswa setuju adanya perangkat ajar di luar jam kuliah yang dapat dipakai untuk mendukung pembelajaran tata bahasa karena mahasiswa menyadari bahwa tata bahasa China sangat sulit karena berbeda sama sekali dengan tata bahasa Indonesia. Dengan demikian, mahasiswa membutuhkan perangkat ajar yang ada jawabannya supaya mereka dapat belajar di luar kelas.
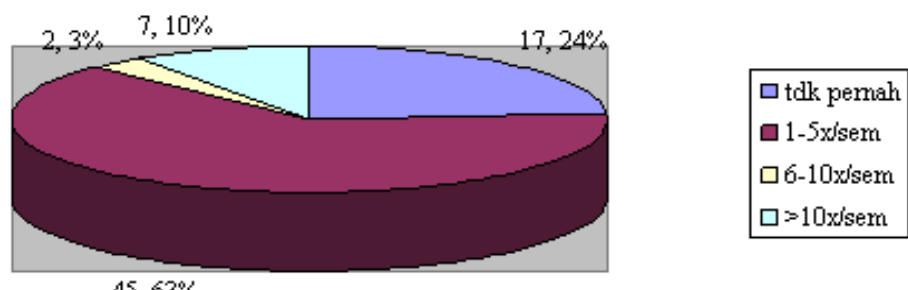

Gambar 15 Tugas BiNus Maya

Dari Gambar 15 dapat diketahui bahwa tugas BiNus Maya yang dikerjakan sangat minim. Hal itu mungkin berhubungan dengan kesulitan mahasiswa dalam membuka animasi bahan pendukung berisi percakapan sehingga mahasiswa mengalami kesulitan menjawab pertanyaan yang diajukan mengenai isi animasi tersebut.

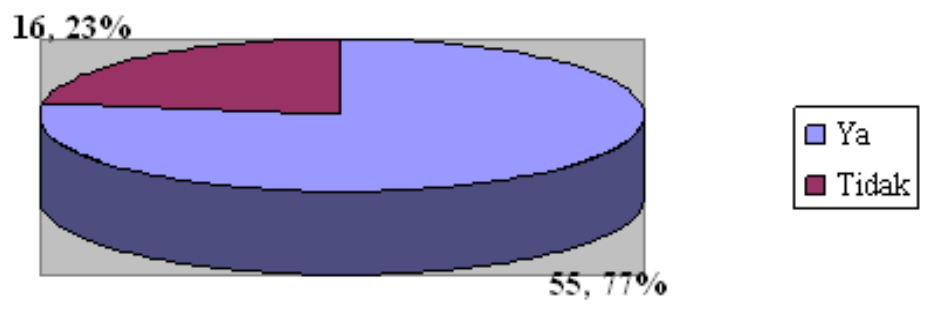

Gambar 16 Kesulitan Mengumpulkan Tugas

Sebagian besar mahasiswa mengalami kesulitan dalam mengumpulkan tugas melalui internet. Hal itu menyebabkan aktivitas di discuscion board berkurang dan mahasiswa lebih cenderung mengumpulkan tugas pada waktu bertemu dosen. 


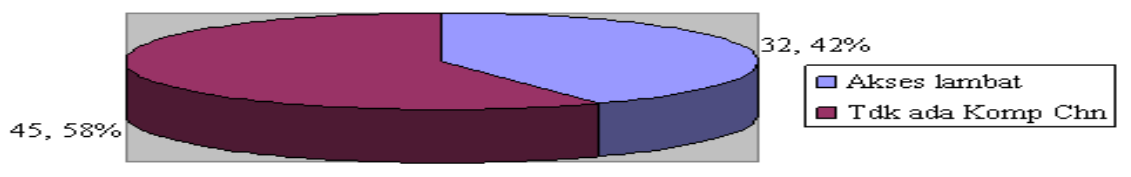

Gambar 17 Kesulitan Mengerjakan Tugas

Sebagian besar mahasiswa mengakui bahwa kesulitan dalam mengumpulkan tugas di BiNus Maya adalah karena tidak adanya komputer yang menggunakan bahasa China, padahal sebagian besar mahasiswa mempunyai komputer. Kendala itu dapat diatasi jika jurusan atau dosen dapat meminjamkan software bahasa China yang dapat di-install ke komputer para mahasiswa.

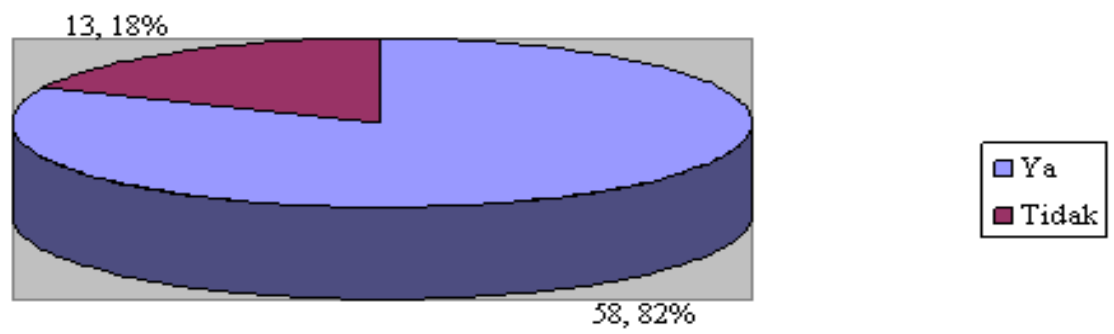

Gambar 18 Kesulitan Animasi Percakapan

Sebagian besar mahasiswa mengalami kesulitan dalam membuka animasi percakapan di intenet. Hal itu dapat dimaklumi karena animasi percakapan membutuhkan space yang besar dan waktu yang diperlukan untuk membukanya juga lama. Hal itu dapat diatasi jika dosen dapat menyimpan animasi percakapan tersebut di CD dan memberikan mahsiswa untuk di-copy. Dengan demikian, pada saat mahasiswa menjawab pertanyaan di forum discussion board, mereka tidak perlu membuka website percakapan.

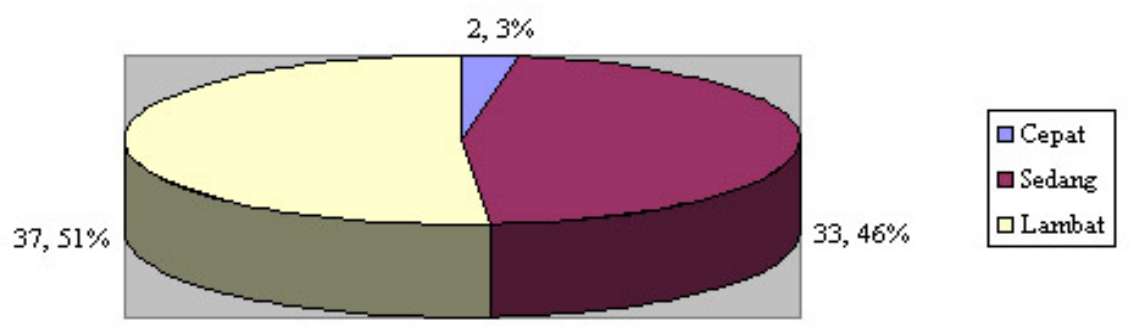

Gambar 19 Kecepatan Akses Animasi di Internet

Dari hasil kuesioner dapat dilihat bahwa 37,51\% mahasiswa merasa jangka waktu yang dibutuhkan untuk membuka animasi di internet lambat. Akan tetapi, 33,46\% mahasiswa merasa jangka waktu yang dibutuhkan tidak terlalu lambat dan tidak terlalu cepat. Kemungkinan besar hal itu tergantung jenis komputer dan waktu mahasiswa download bahan (pagi, siang, sore, atau malam). 


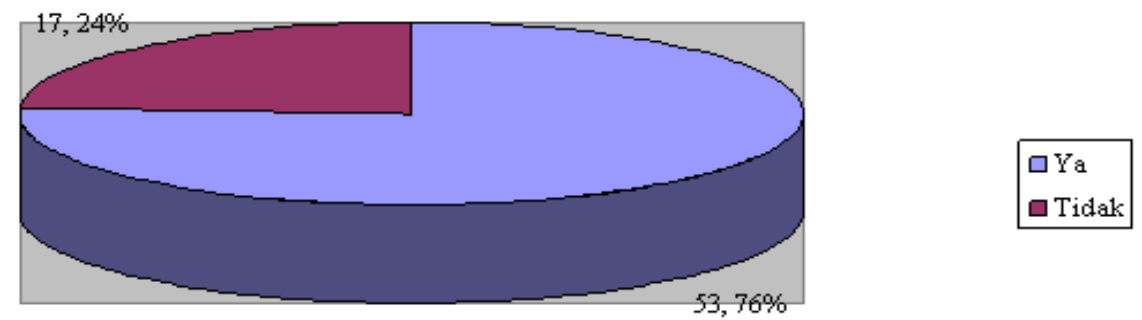

Gambar 20 Kesulitan Pengumpulan Tugas On-Line

Sebagian besar mahasiswa merasa kesulitan jika tugas-tugas latihan yang diberikan hanya dapat dikerjakan on-line. Kemungkinan besar kendala mahasiswa adalah karena mereka tidak mempunyai komputer yang menggunakan bahasa China sehingga pada waktu mereka akan menjawab pertanyaan dosen yang diajukan dalam bahasa China, mereka tidak dapat mengetik jawabannya. Selain itu, bagi mahasiswa yang meng-install software NJ Star hanya dapat mengetik dalam tulisan chinese traditional sedangkan selama ini mahasiswa belajar tulisan chinese simplified.

Sebagian besar mahasiswa merasa tertarik membaca artikel bahasa China di internet. Hal itu merupakan suatu fenomena yang bagus karena menunjukkan keinginan belajar mahasiswa sangat besar. Dengan demikian, dapat memperbanyak bahan pendukung bahasa ajar berbentuk artikel yang berhubungan dengan tata bahasa, nada, dan lafal dan semua bidang ilmu yang berhubungan dengan peningkatan pengetahuan bahasa China.

\section{PENUTUP}

Dari hasil penelitian, diperoleh simpulan sebagai berikut. Pertama, nilai mahasiswa kelas MCL lebih unggul dibandingkan nilai mahasiswa kelas MCL Off Class dan kelas Face to Face (Konvensional). Hal itu menunjukkan pengajaran Bahasa China I lebih baik dengan MCL tetapi tidak off class dibandingkan dengan kombinasi MCL Off Class maupun Face to Face. Kedua, berdasarkan hasil kuesioner didapatkan masukan bahwa bahan pendukung MCL berupa animasi susah dibuka karena beban untuk meng-upload animasi terlalu berat. Hal itu menghabiskan waktu dan biaya mahasiswa menyebabkan mahasiswa mengumpulkan tugas yang diminta pada waktu tatap muka dengan dosen bukan lewat e-mail. Dengan demikian, dosen jarang memberikan tugas di BiNus Maya.

Ketiga, meskipun sebagian besar mahasiswa memiliki komputer di rumah tetapi hal itu tidak mendorong mereka untuk aktif di forum diskusi karena komputer yang dimiliki tidak memiliki software bahasa China sehingga merupakan kendala yang besar dalam berdiskusi mengenai kesulitan belajar yang dihadapi. Keempat, mahasiswa menyadari bahwa dalam mempelajari bahasa China yang menjadi kendala adalah pelajaran tata bahasa. Hal itu karena tata bahasa China berbeda dengan tata bahasa Indonesia. Oleh karena itu, mahaiswa merasa terbantu jika adanya perangkat ajar yang berisi latihan beserta jawaban untuk membantu mereka lebih menguasai kosa kata bahasa China. Keempat, sebagian besar mahasiwa tertarik untuk membaca artikel berbahasa China di internet. Hal itu sangat menggembirakan karena menunjukkan minat mahasiswa untuk belajar mandiri sangat kuat dan keinginan mereka untuk menambah ilmu di luar buku ajar juga sangat besar. 


\section{DAFTAR PUSTAKA}

Kumpulan karya ilmiah Pengajaran Bahasa China oleh Dekan Jin Ning (Dekan Fakultas Bahasa China Universitas Huaqiao, China). 2003.

Kumpulan karya ilmiah Pengajaran Bahasa China di Indonesia dalam rangka Loka Karya Pengajaran Bahasa China Ketiga yang diselenggarakan oleh Suskonsursium Bahasa Mandarin, DIKTI. 2005.

Parera, Jos Daniel. 1994. Linguistik Edukasional. Erlangga, Jakarta.

Preston, Dennis R. 1989. Sociolinguistics and Second Language Acquisition. Oxford and New York: Basil Blackwell.

Rivers, Wilga M. 1981. Teaching Foreign-Language Skills. London: The University of Chicago.

Samsuri. 1991. Analisis Bahasa. Jakarta: Erlangga.

Wheeleer, Steve. "Teknologi Konvergen dalam Sistem Pembelajaran Jarak Jauh (Convergent Technologies in distance learning delivery).” Tech Trends, Volume 43, Issue 5, November 1999, hal 19.

William, C.A.S. 1999. Chinese Symbolism and Arts Motifs. Jakarta: Gramedia.

Verhaar, J.W.M. 1999. Asas-asas Linguistik Umum. Yogyakarta: Gajahmada University Press.

黄伯荣. 1997. 现代汉语(增订二版)下册. 高等教育出版社.

娱华. 2002. 使用现代汉语语法. 商务印书馆.

Landsberger, Joe . "Pedoman dan Strategi Belajar" diakses dari http://www.studygs.net/indon/disted.htm

Pinyin, Hanyu. Diakses dari http://www.chineseon.net/resources/pinyin/index.php

http://www.chineseon.net/course/grammar

http://vlc.polyu.edu.hk/putonghua/unit1/unit1.htm

http://vlc.polyu.edu.hk/putonghua/unit2/unit2.htm

http://www.languageguide.org/im/veg/cn

http://www.languageguide.org/im/fruits/cn

http://www.languageguide.org/im/num/cn

http://shufawest.us/language/tonedrill.html

http://www.languageguide.org/im/dining/cn

http://www.languaguide.org/im/food/cn/ndexz.jsp

http://www.languageguide.org/im/colors/cn

http://www.languageguide.org/im/electronics/cn

http://www.languageguide.org/body/cn 